\title{
Vineyard managers and researchers seek sustainable solutions for mealybugs, a changing pest complex
}

\author{
by Kent M. Daane, Monica L. Cooper, \\ Serguei V. Triapitsyn, Vaughn M. Walton, \\ Glenn Y. Yokota, David R. Haviland, \\ Walt J. Bentley, Kris E. Godfrey \\ and Lynn R. Wunderlich
}

\section{Mealybugs have become increasingly} important vineyard pests - a result of their direct damage to the vine, their role in transmitting grapevine leafroll viruses, and the costs for their control. Numerous mealybug species are found in vineyards, and each has different biological traits that affect sustainable control options. We review the mealybug pests and their natural enemies to provide some clarification about current trends in biological control tactics and needed directions for future work.

$\mathrm{O}$ ver the past 100 years, a series of different mealybug species have been found in California vineyards, with five species currently causing damage and a sixth posing a threat. Mealybugs have needlelike mouthparts that feed on the plant's phloem, which contains the nutrients needed for mealybug development. As mealybugs digest their food, they excrete a sugar-rich fluid called "honeydew." All vineyard mealybugs can feed on the vine's trunk, canes, leaves or fruit, and some species feed on vine roots. Crop loss occurs when mealybugs infest fruit or excrete honeydew that covers fruit and leaves, often resulting in sooty mold growth, defoliation and sunburned fruit. Continuous high levels of infestation over successive years may also lead to the deterioration of vines. And many mealybug species transmit viruses such as grapevine leafroll (see sidebar, page 174). However, these mealybug pests can be controlled, to some extent, by natural enemies that are often present in sustainable management programs.

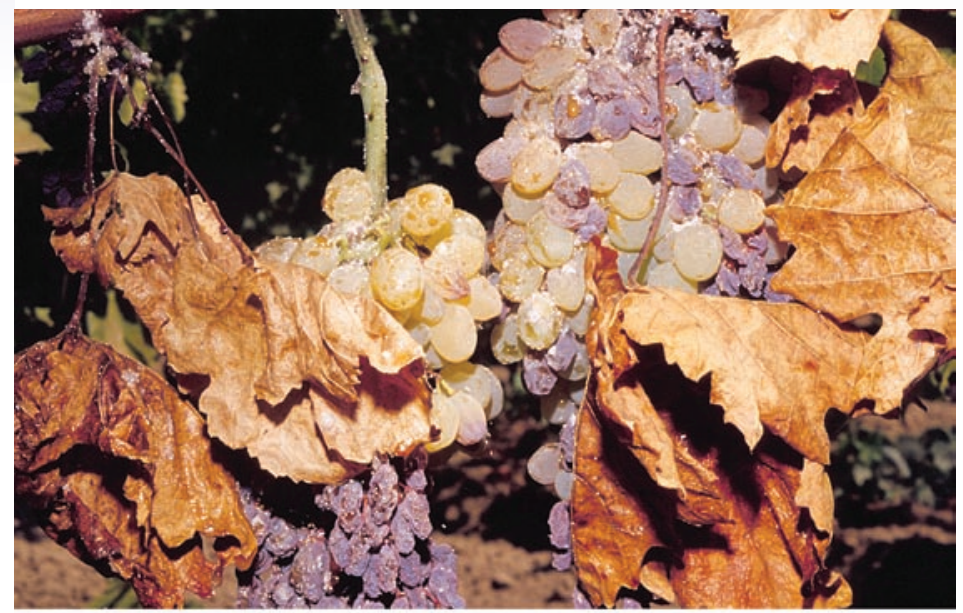

4 In an uncontrolled vine mealybug infestation in a San Joaquin Valley raisingrape vineyard, mealybug and honeydew accumulate on the fruit, canes and leaves.

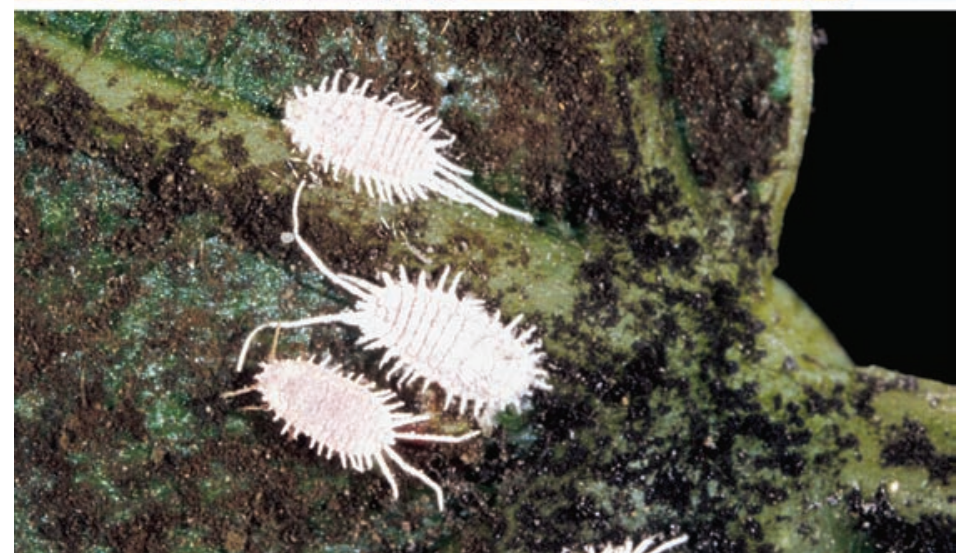

4 An obscure mealybug infestation in a Central Coast wine-grape vineyard shows growth of sooty molds that are often associated with mealybug excretion (honeydew), especially in cooler grape regions.

\section{Mealybug pests}

Most of California's vineyard mealybugs are invasive species - although some of them have been here for nearly 100 years. For newly invasive species, eradication should be the first response. If eradication is not feasible, then an integrated program that includes classical biological controls should be considered. For native mealybug species, resident natural enemies often provide substantial control or can be manipulated to improve their effectiveness. The history of each mealybug species in California and its distinctive biological characteristics affect the level of economic damage and potential effectiveness of biological controls.

Pseudococcus. The grape mealybug, Pseudococcus maritimus (Ehrhorn), is one of the oldest California vineyard pests (Essig 1914). It was first described from specimens collected on coastal buckwheat in California in 1900 and was the only vineyard mealybug thought to be native to North America (Miller et al. 1984) until the arrival of Ferrisia gilli Gullan. Grape mealybugs can be found throughout California's Central Valley and coastal grape regions, as well as in Oregon and Washington vineyards. Typically, there are two generations per year (Geiger and Daane 2001). For most of the year, grape mealybugs are found under the bark, but during the second generation (beginning in June) they move into grape clusters, especially clusters in contact with the trunk or spurs. The population overwinters as eggs or small nymphs under the bark, with a required diapause that helps to synchronize generations each year.

The longtailed mealybug, Pseudococcus longispinus (Targioni Tozzetti) is believed to be of Austro-Oriental origin 

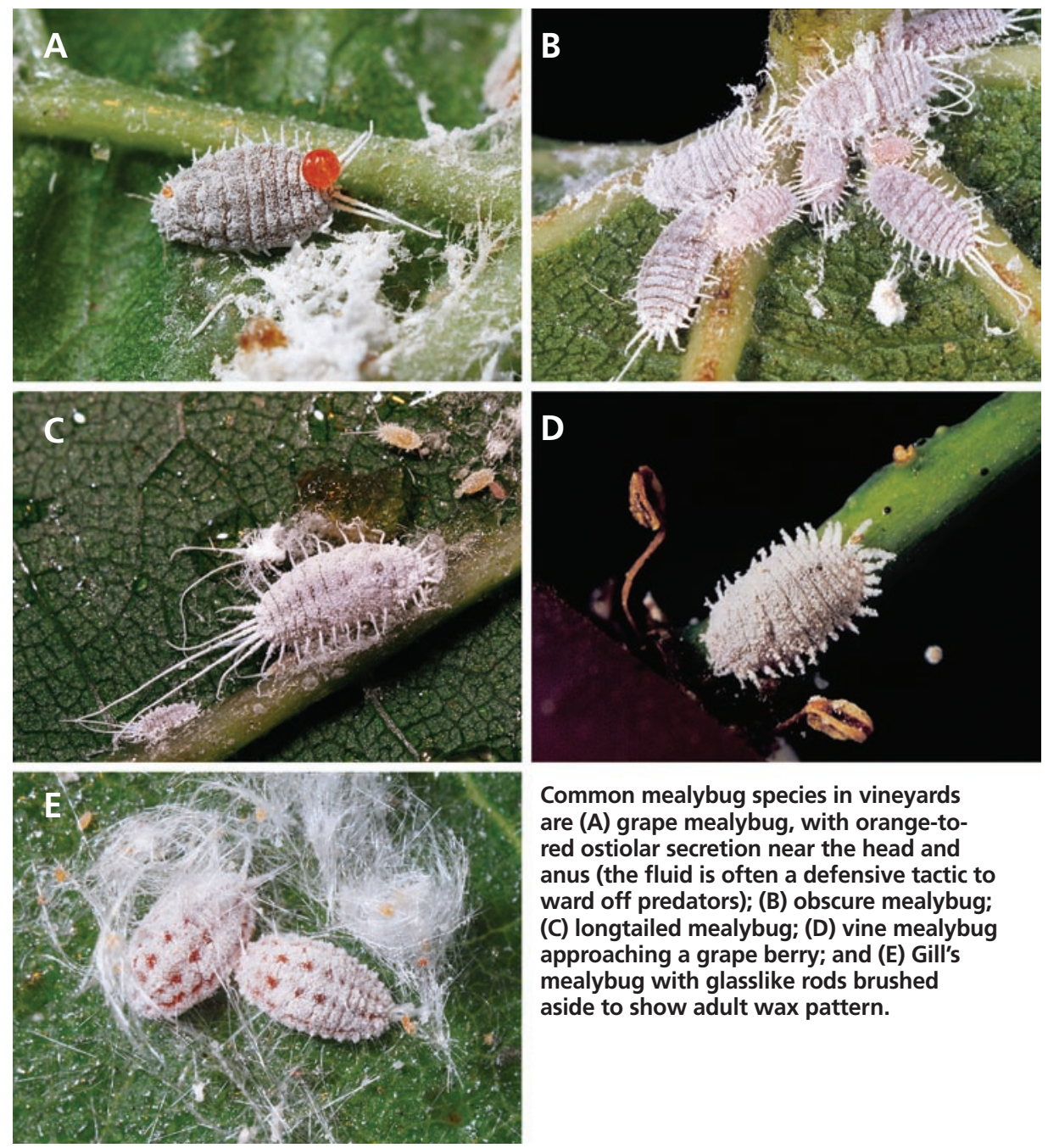

Common mealybug species in vineyards are (A) grape mealybug, with orange-tored ostiolar secretion near the head and anus (the fluid is often a defensive tactic to ward off predators); (B) obscure mealybug; (C) longtailed mealybug; (D) vine mealybug approaching a grape berry; and (E) Gill's mealybug with glasslike rods brushed aside to show adult wax pattern.

(Ben-Dov 1994). This cosmopolitan species has been resident in California since at least 1933 and is best known as a pest of ornamental plants. Longtailed mealybug has been limited to Central Coast vineyards, where it has three generations yearly. Unlike the other Pseudococcus species discussed, longtailed mealybugs give birth to live crawlers (1st-instar mealybugs, which disperse before they settle and feed) rather than depositing eggs.

The origin of the obscure mealybug, Pseudococcus viburni (Signoret), is unknown, and both Australia and South America have been suggested. While known to be in North America since the early 1900s, its history is poorly documented due in part to earlier taxonomic confusion - it is a close relative of the grape mealybug and was often misidentified (Miller et al. 1984). The obscure mealybug is primarily a pest of ornamental plants but is also found in coastal vineyards, especially in association with the Argentine ant, Linepithema humile (Mayr) (Phillips and Sherk 1991).
Biological traits that make obscure mealybug more damaging than grape mealybug are that it readily feeds on leaves (causing leaf damage and raining honeydew down onto grape clusters), it can survive on common weeds such as malva and burclover (Walton and Pringle 2004b), it has three or four overlapping generations per year, and it excretes more honeydew. It is limited, however, to the cooler grape-growing regions, and is most commonly found in Central Coast vineyards.

Planococcus. The vine mealybug, Planococcus ficus (Signoret), is a relatively new invasive species to Californian and Mexican vineyards (Daane et al. 2006). In 1994, it was found in Coachella Valley table grapes, although it probably entered the state years before. Vine mealybug has always been associated with vineyards and was first identified as a new species in the Crimea on grapes in 1868. It has since spread and is now a key pest in the vineyards of Europe, northern
Africa, South Africa, Argentina, the Middle East and Mexico. In California, crawlers blown by wind or carried by animals and farm machinery aid its spread. Infested nursery stock (Haviland et al. 2005) and pomace from the wine-grape crush (see sidebar, page 172) can also harbor this pest.

Vine mealybug has a number of traits that make it particularly damaging and difficult to control. Most notably, there are four to seven annual generations in much of California's grape-growing regions, resulting in rapid population growth. Vine mealybug also feeds on all parts of the vine throughout the season, resulting in a portion of the population protected under the bark. It can feed on a number of plant species; however, while it is common in Europe on fig (Ficus sp.), there are no reports on this host from California. The closely related citrus mealybug, Planococcus citri (Risso), has been found on vines but has never been recorded as an economically important pest in vineyards.

Ferrisia. Ferrisia gilli Gullan is a close relative of the striped mealybug (F. virgata Cockerell), which is probably native to southeastern North America. In fact, until recently the California population was considered to be the striped mealybug, but differences in its adult morphology and economic importance in pistachios and almonds prompted studies that led to its new species description in 2003 (Gullan et al. 2003). Damaging vineyard populations have only recently been found in the Sierra foothills. Because F. gillicommonly called Gill's mealybug, after Raymond Gill - is so new to scientists, research on its seasonal occurrence has, to date, only been conducted on pistachios grown in the Central Valley (Haviland et al. 2006). There, the mealybug has three annual generations. In fall, adult females produce crawlers that overwinter in protected crevices of the trunk and scaffolding branches. During bud-break, the overwintering nymphs migrate to buds to feed; they become adults between late May and mid-June and give live birth to crawlers, the first of two in-season generations. Currently, studies are ongoing in El Dorado County to determine this mealybug's seasonal occurrence on grapes. 
Maconellicoccus. The pink hibiscus mealybug, Maconellicoccus hirsutus (Green), is an excellent example of an invasive species that presents a significant threat to California grapes but has been limited by a successful classical biological control program (Roltsch et al. 2006). Pink hibiscus mealybug is probably native to Southeast Asia or Australia. It invaded Egypt in 1912, Hawaii in 1984, the Caribbean islands in 1994, Florida in 2002, and reached northern Mexico and Southern California in 2003. It has a wide host range of more than 200 plant species. Under optimum temperature conditions, this mealybug can have explosive populations with more than 600 eggs per ovisac and up to 15 generations per year.

\section{Natural enemies}

Hundreds of natural enemies can attack mealybugs, making this brief review incomplete. Here, we catalog the more common natural enemies and their potential impact.

A number of predators contribute to mealybug control; a few specialize on mealybugs, while most are generalists that prey on any small, soft-bodied arthropods. For many of these natural enemies, there are no studies of their impact on mealybug populations.

Mealybug destroyer. One of the more effective and specialized predators is the "mealybug destroyer," Cryptolaemus montrouzieri Mulsant. This lady beetle was imported to California from Australia in 1891 to help control the citrus mealybug (Bartlett et al. 1978). Both adults and larvae kill mealybugs. The larvae are mealybug mimics. They have waxlike filaments similar to those of mealybugs and this "camouflage" allows beetle larvae to feed amongst mealybugs without too much disturbance from mealybug-tending ants (Daane et al. 2007). One drawback is the predator's poor tolerance to winter temperatures (Smith and Armitage 1920). In 1996, a "cold-hardy" strain of the mealybug destroyer was collected in southern Australia and released in California (K.S. Hagen, unpublished data). Material from these releases appears to have established and, currently, the mealybug destroyer is found throughout the coastal wine-grape regions (Daane, personal observation).
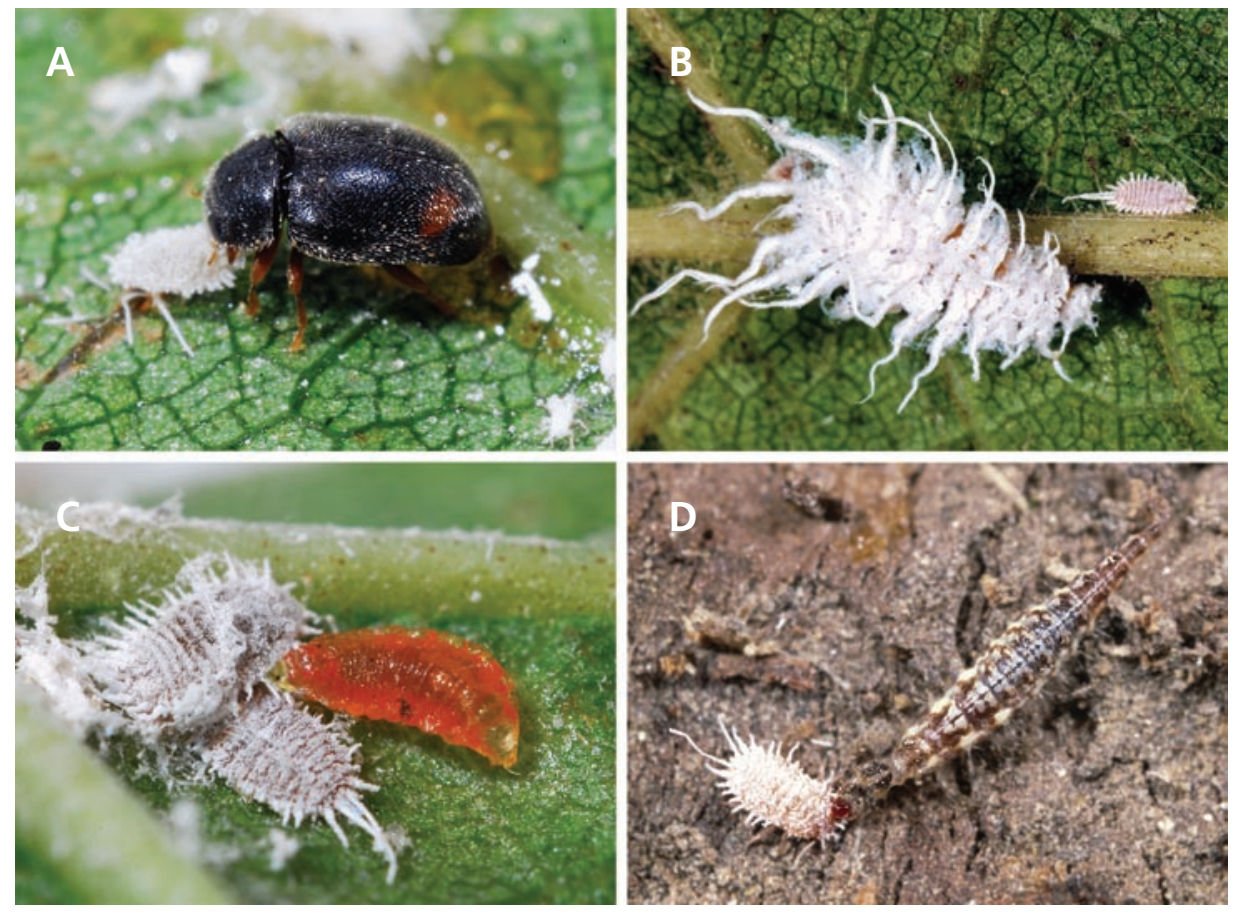

Common mealybug predators include lady beetles. (A) An adult Scymnus species feeds on a grape mealybug. (B) A large mealybug destroyer larva near the smaller obscure mealybug; the larvae of many of these lady beetle species have waxy filaments to mimic mealybugs and reduce interference from mealybug-tending ants. (C) A cecidomyiid larva prepares to feed on grape mealybugs. (D) A third-instar green lacewing (Chrysoperla carnea) larva attacks a grape mealybug, prompting it to secrete a ball of red ostiolar fluid in defense.

Other beetles. Other lady beetle species also attack mealybugs. Many beetle larvae in the subfamily Scymninae are covered with wax, similar to the mealybug, and are often mistakenly identified as the mealybug destroyer. These include species of Hyperaspis, Nephus (=Scymnobius) and Scymnus, commonly the most abundant mealybug predators in infested vineyards. Some of these beetles, such as Nephus bineavatus (Mulsant), were imported for mealybug control from South Africa in 1921; others are thought to be native to North America. These species may not be as dependent on high mealybug pest populations as the mealybug destroyer and therefore, may be more important predators in vineyards with lower mealybug population densities. However, because the taxonomic keys for these Scymninae beetles poorly differentiate among species, many of the observed beetles are never properly identified. Migratory lady beetles, notably those in the subfamily Coccinellinae, are often attracted to large mealybug infestations and their honeydew; these include some of the large and recognizable species such as the convergent lady beetle (Hippodamia convergens Guérin-Méneville) and transverse lady beetle (Coccinella transversoguttata [Falderman]). There are no studies of any of these beetles' impact on California mealybugs.

Lacewings. Lacewings have long been associated with mealybugs. In fact, Doutt and Hagen (1950) first reported that the golden-eyed green lacewing (Chrysoperla carnea [Stephens]) suppressed grape mealybugs in pears. Surveys of coastal vineyards infested with mealybugs found C. carnea, Chrysoperla comanche Banks and an unidentified Chrysopa Leach (Daane et al. 1996). Lacewing larvae are effective predators of smaller mealybugs, although they have a more difficult time feeding on eggs in the mealybug ovisac, where waxy secretions provide some protection from the lacewing larva's mouthparts, or on larger mealybugs, which excrete ostiolar fluid that can act as a defensive mechanism. Often overlooked, brown lacewings may be important mealybug predators in spring because they are present and active at cooler temperatures (Neuenschwander and Hagen 1980). Common brown lacewing species are Hemerobius pacificus Banks, Sympherobius californicus Banks and S. barberi Banks. No studies docu- 

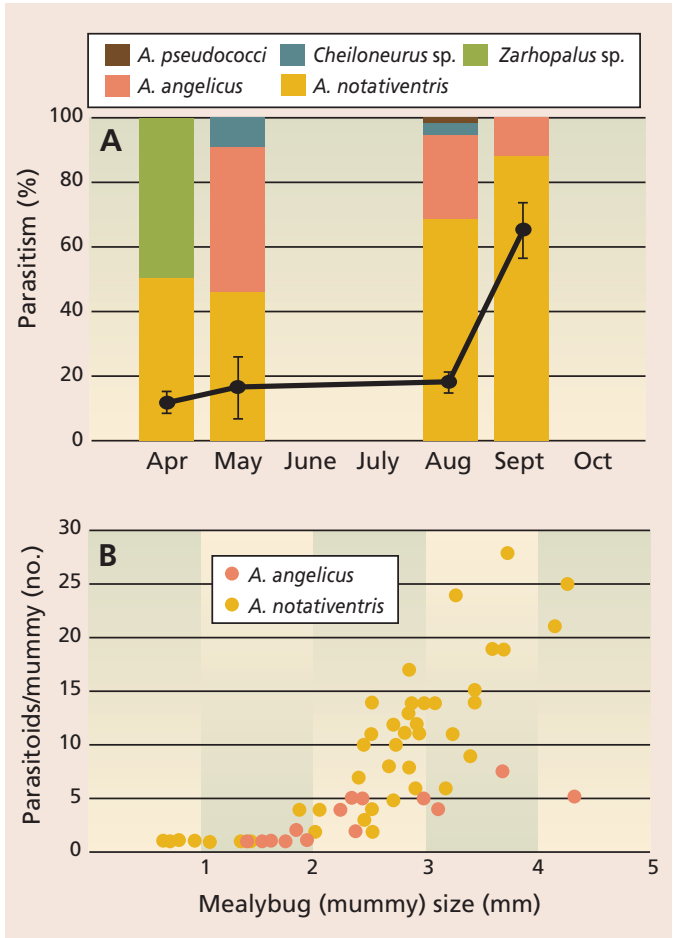

Fig. 1. (A) Percentage parasitism (0) of grape mealybug collected in three San Joaquin Valley vineyards, with bar graphs showing species composition of parasitoids reared on each sample date (Cheiloneurus is a hyperparasitoid). (B) Number of Acerophagus angelicus and $A$. notativentris reared from mealybugs increased with increasing mealybug size. Source: Daane et al. 2001.

ment the impact of green or brown lacewings on mealybugs in California vineyards.

Flies/midges. Cecidomyiid flies predaceous midges - are another common mealybug predator. One midge species documented in California vineyards is Dicrodiplosis californica Felt (Geiger and Daane 2001). The adult fly, which is not predatory, deposits eggs in or near the mealybug ovisac and the maggotlike larvae feed, primarily, on mealybug eggs and small larvae. The fly larvae typically pupate in the ground. Unfortunately, little is known about these predators in California vineyards. In New Zealand, Charles (1985) reported that Diadiplosis koebelei (Koebele) reduced longtailed mealybugs by about $30 \%$.

Other predators. Minute pirate bugs (Orius spp.), damsel bugs (Nabis americoferus Carayon), big-eyed bugs (Geocoris pallens Stål), European earwigs (Forficula auricularia Linnaeus) and predaceous mites have all been observed to feed on mealybugs, but are not commonly found in large numbers in vineyards. Spiders are the largest group, often comprising more than $90 \%$ of arthropod predators found in vineyards (Costello and Daane 1999). Some spiders, such as Theridion spp., have been observed feeding on mealybugs in vineyards. These generalist predators are assumed to play a secondary role behind the more specialized predators and parasitoids.

\section{Parasitoids - tiny wasps}

Some of the most important mealybug natural enemies are Hymenoptera, or more specifically, tiny encyrtid and platygastrid wasps (Noyes and Hayat 1994). Depending on the species, these "internal parasitoids" deposit one (solitary) or many (gregarious) eggs inside the mealybug. The parasitoids are classified as "koinobionts" because the parasitized mealybug is, initially, active (still feeding and moving). As the parasitoid larva grows internally the mealybug becomes sluggish and eventually does not move, producing no new wax filaments and forming a golden-brown "mummified" mealybug. The mummy helps protect the developing larval parasitoid(s) inside. The larvae pupate inside the mealybug and the adult parasitoid emerges by chewing a hole through the mummy. Because mealybug parasitoids can be quite specialized, we discuss the complex present in California for each mealybug group.

Grape mealybug. Parasitoids thought to be native to North America have long been credited with grape mealybug control, although the species composition has changed over the years. Smith (1916) and Clausen (1924) reported up to $80 \%$ parasitism of grape mealybugs collected in the Central Valley. In these pre-1930s surveys, Zarhopalus corvinus (Girault) was the dominant parasitoid; others were Anagyrus yuccae (Coquillet), Acerophagus notativentris (Girault), Anagyrus clauseni Timberlake and Pseudleptomastix squammulata Girault. More recent surveys found lower parasitism levels and a change in the parasitoid species complex.

Surveys in the 1970s found that Acerophagus (=Pseudaphycus) notativentris was the dominant parasitoid (Flaherty et al. 1982), and later surveys found Acerophagus angelicus (Howard) and $A$. notativentris were common while $Z$. corvinus was less important (fig. 1A). Both Acerophagus species are gregarious, depositing more eggs in larger mealybugs (fig. 1B); these are the same key parasitoid species found on grape mealybug in Oregon and Washington (Grimes and Cone 1985; Grasswitz and Burts 1995). In the 1940s, a number of parasitoid species were imported from Africa to control grape mealybug (Bartlett et al. 1978). The fact that none of these parasitoids established provided further evidence that the grape mealybug is native to North America and that the parasitoid species found here may be the most specific to this mealybug pest.

Longtailed mealybug. Soon after longtailed mealybug was found infesting California citrus in 1933, a number of parasitoid species were imported. The most important were Tetracnemoidea sydneyensis (Timberlake) from Australia, Anagyrus fusciventris (Girault) from Hawaii and Tetracnemoidea peregrina (Compere) from Argentina. DeBach et al. (1949) suggested that parasitoids helped suppress longtailed mealybug in Southern California, but that predators, especially the mealybug destroyer, were more important. Recent surveys of longtailed mealybug in coastal vineyards reared a number of parasitoid species including T. sydneyensis, T. peregrina, A. angelicus, Anagyrus pseudococci (Girault), Leptomastidea abnormis (Girault), Leptomastix dactylopii Howard and Coccidoxenoides perminutus Girault (Daane et al. 2008). Most of these were imported to control other mealybug species, such as the citrophilus (Pseudococcus calceolariae [Maskell]) or citrus mealybugs. Despite a long list of natural enemies, outbreaks of longtailed mealybug still occur in Central Coast vineyards, primarily in the Santa Maria appellation.

Obscure mealybug. Prior to 1993, there were no effective parasitoid species of the obscure mealybug in California. For this reason, Acerophagus flavidulus (Brèthes) and Leptomastix epona (Walker) were imported from Chile in 1996. Both L. epona and A. flavidulus were initially recovered; however, foraging ants diminished the success of these natural enemies (fig. 2A), resulting in higher mealybug densities (fig. 2B). Currently, only A. flavidulus is reported as established 

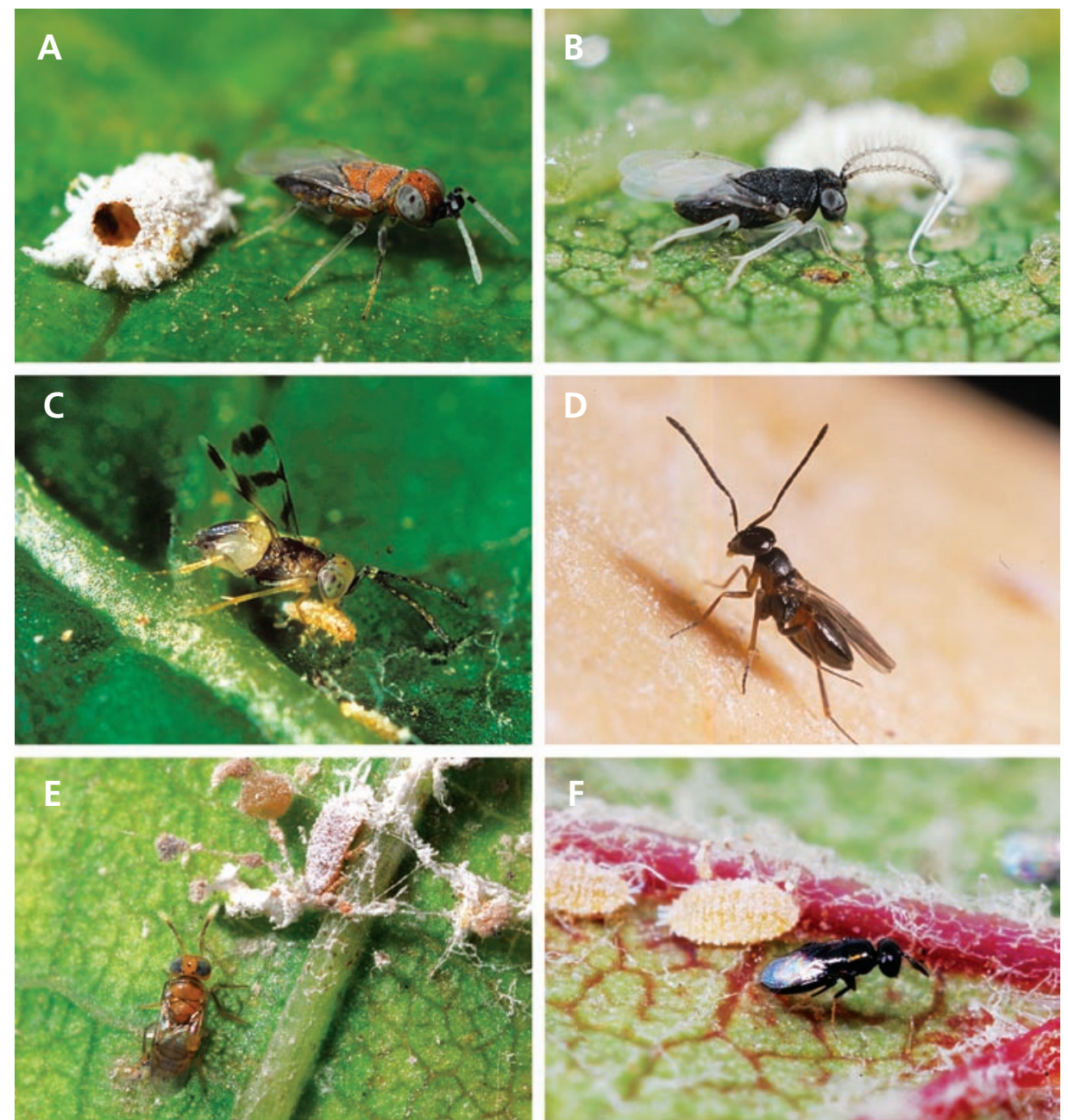

Many parasitoid species attack mealybugs, including: (A) a female Anagyrus pseudococci (ca. $2 \mathrm{~mm}$ ) near a vine mealybug mummy showing the round parasitoid exit hole; (B) the smaller (ca. $1.3 \mathrm{~mm}$ ) male $A$. pseudococci, which has a different color pattern and hairy antennae, feeds on a drop of honeydew; (C) a female Leptomastidea abnormis host-feeds on a vine mealybug crawler; (D) Leptomastix epona was imported for obscure mealybug biological control but did not establish because of Argentine ant interference; (E) the small (ca. 1 $\mathrm{mm}$ ) and fast-moving Acerophagus flavidulus closes in on an obscure mealybug; and (F) Coccidoxenoides perminutus (ca. $1 \mathrm{~mm}$ ) near a vine mealybug first instar.
(Daane et al. 2008). Acerophagus maculipennis (Mercet) was recently imported from New Zealand, where it effectively controls obscure mealybug, and is currently undergoing nontarget host evaluation in the UC Berkeley quarantine.

Vine mealybug. The newly invasive vine mealybug has become the most serious mealybug pest in California vineyards (Daane et al. 2006). From 1995 to 1999, parasitoids were imported from Argentina, Spain, Israel and Turkmenistan, and included A. pseudococci, L. abnormis, C. perminutus and L. dactylopii (González 1998). These species were already present in California, brought in to control the citrus mealybug; however, the newly imported material may have biological characteristics better suited to environmental conditions in California vineyard re- gions. Currently, A. pseudococci, a solitary parasitoid, is the dominant natural enemy of vine mealybug throughout the state, and has a development rate and temperature tolerances that most closely match those of the vine mealybug (Gutierrez et al. 2008).

However, two biological traits reduce levels of natural control. First, overwintered A. pseudococci remain in an immature stage inside the mealybug until late April to early May (fig. 3A), delaying their period of activity until after the mealybug is active. Second, the parasitoid does not effectively forage under the vine bark (fig. 3B), where the mealybug finds refuge. An ongoing program is evaluating the biology and molecular identification of A. pseudococci populations collected in Europe and the Middle
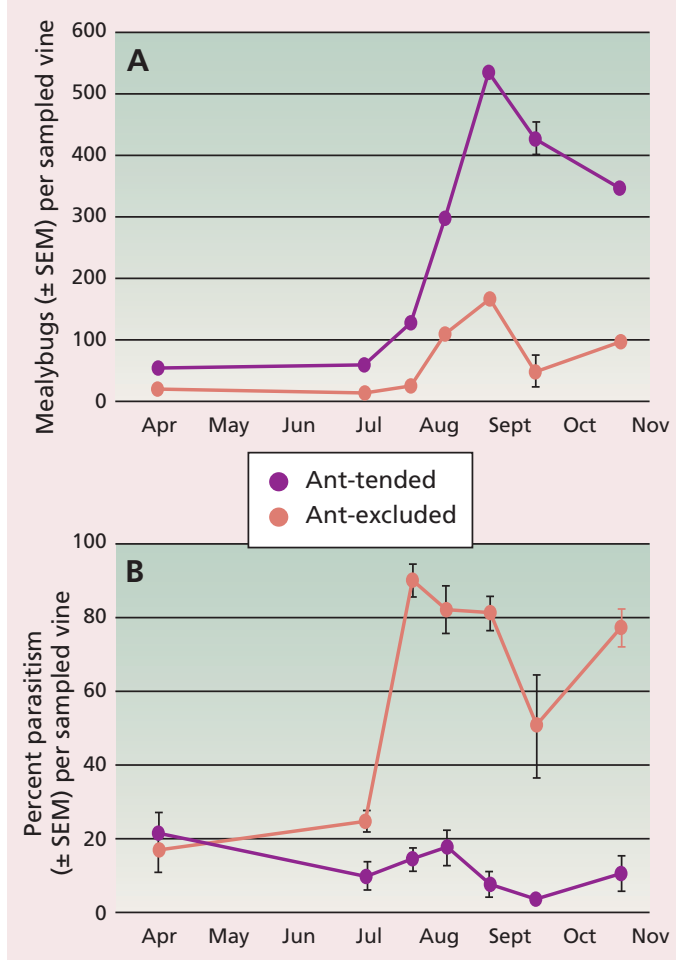

Fig. 2. Mealybug and parasitism levels per vine, based on 3 min. timed counts, in ant-tended and ant-excluded treatments for (A) obscure mealybug density and (B) percentage parasitism of obscure mealybug. Source: Daane et al. 2007.
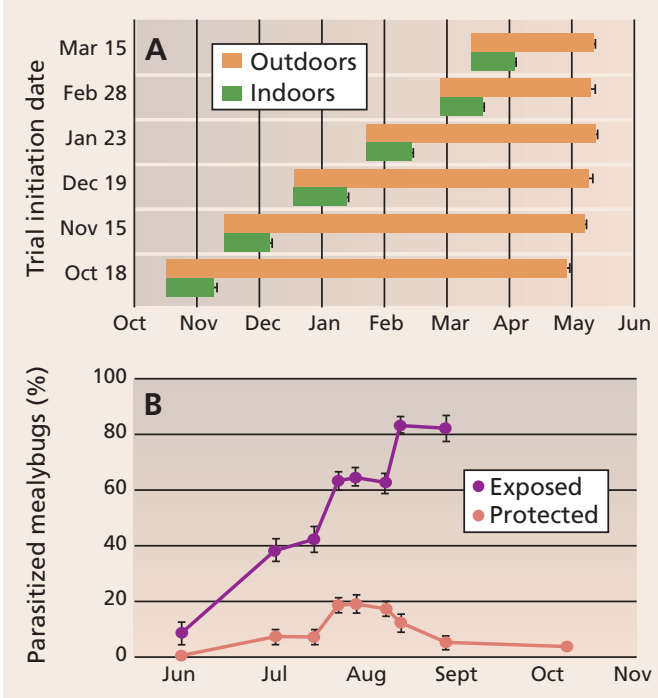

Fig. 3. (A) Average emergence periods for Anagyrus pseudococci on vine mealybug that were exposed to the parasitoid from October through March, and then stored either inside at room temperature or outside at ambient air temperatures for Fresno County. Source: Daane et al. 2004. (B) Percent parasitism of vine mealybugs (collected during a timed count) separated by location where mealybugs were collected as exposed (e.g., on leaves) or protected (e.g., under bark). Source: Daane et al. 2006. 


\section{Pomace management reduces spread of vine mealybugs}

by Rhonda J. Smith and Lucia G. Varela

A fter vine mealybug was first identified in North Coast wine-grape vineyards in 2002, growers and wineries needed answers to reduce the movement of this pest between vineyards. We investigated the potential for vine mealybugs to survive in one type of winery waste (or pomace) that is often spread over the vineyard floor during the harvest period.

The pomace we investigated contains unfermented berry skins, seeds and cluster stems. This fresh material is produced by pressing hand-harvested whole clusters or mechanically harvested berries; the juice is then fermented. Alternatively, clusters are processed by a destemmer-crusher, after which skins and seeds are fermented with the juice, producing sediment also known as pomace. Because insects do not survive the fermentation process, we focused on the survival of vine mealybug in fresh pomace collected from the winery press after whole clusters were pressed, as well as in piles of fresh pomace placed on the vineyard property.

\section{Mealybug survival after whole-cluster} press. Two trials were conducted in wineries located in Sonoma County to determine if vine mealybug survived whole-cluster pressing. In the first trial, a 6-ton load of inregime ranging from 0.2 to 1.8 bars of pressure. Before pressing, we found an average of 47 live vine mealybugs per cluster. After the press was completed, there were an average of 0.04 live vine mealybugs per cluster $(0.085 \%$ survival). In the second trial, single infested clusters were placed inside mesh bags and added to a 12-ton load of 'Chardonnay' grapes that underwent a found an average of over 4,800 vine mealyfested 'Grenache' grapes underwent a press similar press regime. Before pressing, we

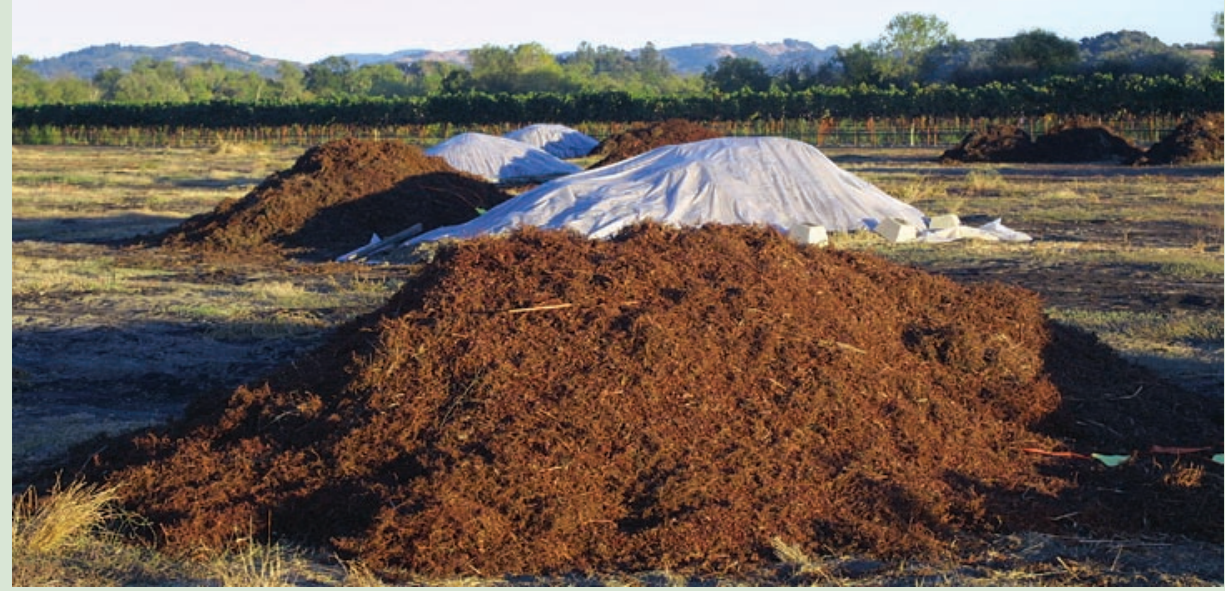

Pomace piles were covered with clear plastic or remained uncovered to evaluate vine mealybug survival. bug crawlers (the small immature stage) per cluster. Afterward, this dropped to an average of 192 crawlers per cluster (4.0\% survival).

These trials showed that vine mealybugs can survive whole-cluster pressing. As a result, fresh pomace can be a source of vine mealybug contamination for wineries or growers who traditionally spread this harvest residue directly in the vineyard or who stockpile unmanaged piles of it near the vineyard.

\section{Controlling mealybugs in pomace.} Another experiment evaluated vine mealybug mortality in static pomace piles that were either uncovered or covered with clear plastic. Infested cluster stems were placed inside mesh bags that were then inserted 1-foot (0.3 meter) and 3 -feet ( 0.9 meter) deep into pomace piles that were 4 feet (1.2 meters) tall and 15 feet $(4.5$ meters) across, approximately the size of piles created by dump trucks commonly used by wineries. Initially, the
TABLE 1. Reduction in vine mealybug on cluster stems after 1 and 4 weeks in two depths, in covered and uncovered pomace piles

\begin{tabular}{|c|c|c|c|c|}
\hline \multirow[b]{2}{*}{ Treatment } & \multirow[b]{2}{*}{ Pile composition } & \multirow{2}{*}{$\begin{array}{l}\text { Infested stem } \\
\text { position in pile }\end{array}$} & \multicolumn{2}{|c|}{ Reduction in vine mealybug } \\
\hline & & & Week 1 & Week 4 \\
\hline & & & ...... & $\ldots \ldots \ldots$ \\
\hline \multirow[t]{4}{*}{ Uncovered piles } & \multirow[t]{2}{*}{ Mostly stems } & Top & 67.6 & 89.4 \\
\hline & & Bottom & 60.7 & 87.5 \\
\hline & \multirow{2}{*}{$\begin{array}{l}\text { Mostly skins and seeds; } \\
\text { few stems }\end{array}$} & Top & 99.9 & $>99.9$ \\
\hline & & Bottom & 99.9 & 100 \\
\hline \multirow[t]{4}{*}{ Covered piles } & \multirow[t]{2}{*}{ Mostly stems } & Top & $>99.9$ & 100 \\
\hline & & Bottom & 100 & 100 \\
\hline & \multirow{2}{*}{$\begin{array}{c}\text { Mostly skins and seeds; } \\
\text { few stems }\end{array}$} & Top & 100 & 100 \\
\hline & & Bottom & $>99.9$ & $>99.9$ \\
\hline
\end{tabular}

clusters had an average of 1,211 live vine mealybugs per stem.

Results showed that vine mealybug mortality was higher when pomace piles were covered for 1 to 4 weeks with clear plastic than when piles were left uncovered (table 1). When uncovered, more vine mealybugs survived in piles consisting of mostly stems discarded from the destemming process than in the denser, moister piles composed primarily of berry skins and seeds from the whole-cluster press. Uncovered piles composed primarily of stems had greater survival of vine mealybug over time because these piles did not generate high enough temperatures to kill vine mealybugs.

In contrast, when pomace piles were covered, vine mealybugs were reduced by nearly $100 \%$ in both "stemmy" and nonstemmy piles. In addition, when covered there was no difference in mortality at different depths in either type of pile. Fresh pomace piles generate heat as organic material degrades. Temperature loggers recorded significantly lower fluctuation at higher temperatures of $120^{\circ} \mathrm{F}$ to $130^{\circ} \mathrm{F}\left(50^{\circ} \mathrm{C}\right.$ to $55^{\circ} \mathrm{C}$ ) in pomace piles with fewer stems and more moisture, than at temperatures of $68^{\circ} \mathrm{F}$ to $130^{\circ} \mathrm{F}\left(20^{\circ} \mathrm{C}\right.$ to $\left.55^{\circ} \mathrm{C}\right)$ in piles with a greater mass of cluster stems, which are slower to break down (data not shown).

Recommendations. To reduce the risk of contaminating vineyards with mealybugs, growers should avoid spreading pomace in vineyards unless it has been 
covered with plastic for at least 1 week. Optimally, pomace piles should be located away from vine rows and securely covered as soon as feasible, so heat that is generated remains inside the pile. To help increase temperatures inside stemmy piles and decrease vine mealybug survival, cluster stems collected from a winery's destemmer should be mixed with dense material, such as pomace from either whole-cluster or mechanically harvested press loads. Frontend loaders, which are commonly used in many wineries, may be used to mix pomace piles to some degree.

We did not evaluate the survival of vine mealybug in composted pomace. At facilities required to obtain a Compostable Materials Handling Facility Permit from the California Integrated Waste Management Board, regulations require that the windrow composting process under aerobic conditions maintain a temperature of $131^{\circ} \mathrm{F}$ $\left(55^{\circ} \mathrm{C}\right)$ or higher for 15 days or longer to reduce pathogens. During that period, the windrow must be turned a minimum of five times. Given these rigorous requirements, this process is likely to result in similar or increased mortality of vine mealybugs compared to static, covered pomace piles.

Sanitation practices are recommended to avoid spreading any species of mealybug. Many wineries, regardless of size, find it challenging to cover pomace with clear plastic as it is generated. During the harvest period, pomace may be produced daily at a rate of approximately a ton of pomace for every 3 to 6 tons of grapes, so the lack of space to store and manage this material away from grapevines is a critical problem. Bins and dump trucks that are used to move pomace during the production process may potentially contaminate subsequent loads of fresh grapes with mealybugs. Containers used to haul grapes and pomace should be cleaned with a high-pressure sprayer before they are moved offsite.

R.J. Smith is Viticulture Farm Advisor, UC Cooperative Extension (UCCE), Sonoma County; and L.G. Varela is Integrated Pest Management (IPM) Advisor, UC Statewide IPM Program and UCCE Sonoma County. This study was funded in part by the USDA Exotic/Invasive Pests and Diseases Research Program.
East, noting that this parasitoid is probably a complex of more than one species (Triapitsyn et al. 2007) and other "strains" may be better suited for California.

Gill's mealybug. Very little is known about parasitoids of $F$. gilli, as this species was only described in 2003. From collections of F. gilli in El Dorado County vineyards, as well as San Joaquin Valley almonds, it appears that Acerophagus sp., Chrysoplatycerus sp. and Anagyrus pseudococci will attack F. gilli. High levels of parasitism have been recorded by Acerophagus sp. nr. meritorius (Gahan) or A. sp. nr. mundus (Gahan) (the species cannot be determined because of indecisive species descriptions and poor type specimens [Daane et al. 2008]). The Acerophagus sp. was most likely present in California as a parasitoid of the closely related striped mealybug, Ferrisia virgata. Currently, research is investigating parasitism levels of F. gilli in Sierra Foothill vineyards.

Pink hibiscus mealybug. In India, the pink hibiscus mealybug is a major pest of grapes, reducing yields 50\% to $100 \%$. That it is not a pest in California vineyards may be the direct result of a successful biological control program that has limited its spread in the state. After the mealybug was found in the Caribbean in 1994, a cooperative classical biological control project was established for that region, and later extended to California when the pink hibiscus mealybug was found south of the Coachella Valley table-grape region. The parasitoids Anagyrus kamali Moursi, Gyranusoidea indica Shafee, Alam \& Agarwal and Allotropa sp. nr. mecrida (Walker) were released and, over a 5-year period, mealybug density progressively declined to noneconomic levels (Roltsch et al. 2006). Currently, pink hibiscus mealybug populations are maintained at low levels by these natural enemies, and the pest populations have been contained in the very southern portion of the state - currently out of vineyard growing areas.

\section{Manipulating natural enemies}

Insecticides. Vineyard mealybugs are often controlled with insecticides. Prior to the 1990s, most insecticides were not compatible with biological controls. For example, early grape mealybug controls included fumigation with potassium cyanide (Essig 1914), and later materials included DDT and organophosphates (e.g., parathion) (Stafford and Kido 1955). Eventually it became evident that the insecticidal materials disrupted the relatively good control provided by parasitoids. Flaherty et al. (1982) stated that "extensive use of DDT and other synthetic insecticides used to control grape leafhopper disrupted natural control of grape mealybug." Currently, there are many effective materials, such as systemic neonicotinoids, insect growth regulators and tetronic acids that inhibit lipid biosynthesis, which can be used with reduced impact on natural enemy populations. Use of these more narrowspectrum materials may have a less disruptive effect on biological controls.

Ant controls. Ants can exacerbate mealybug pest problems by disrupting natural enemy activity in vineyards (Daane et al. 2007). Unfortunately, insecticide controls for ants are often more disruptive than materials applied for the mealybugs. For that reason, researchers have developed protein and sugar baits for ant control in vineyards, which can be effective alternative practices (see page 177).

Augmentation. There are few reports of successful augmentation when natural enemies are reared in an insectary and released into the targeted habitat - for mealybug control in vineyards, in part because this has not been adequately studied.

In fact, one of the first commercial insectaries in North America was developed in 1916 to rear the mealybug destroyer for the citrus mealybug (Smith and Armitage 1920). Today, this beetle is commonly released in vineyards, but release rates, timing and expected outcomes have not been scientifically evaluated. Until those studies are conducted, understanding the biology of the mealybug destroyer may help improve release effectiveness. Beetles are sold as adults and when released into the vineyard they typically begin searching for mealybug ovisacs, where they will deposit eggs. If no ovisacs are found, many of the beetles may fly away; therefore, releases should be timed to coincide with the presence of ovisacs (or females depositing crawlers in the case of the longtailed mealybug). 
The beetle is most commonly found in vineyards with many mealybugs and may not be as effective at low mealybug densities. This suggests the beetle may be best used by releasing at hot spots where the mealybug density is high.

Green lacewings are one of the more common commercially produced natural enemies. One of their first successful uses in augmentation was against the grape mealybug infesting pears in California (Doutt and Hagen 1950). In vineyards, the only published studies were of green lacewing releases targeting leafhopper pests (Daane and Yokota 1997), and on the performance of mechanically released lacewing eggs into a vineyard canopy (Wunderlich and Giles 1999). Daane and Yokota's work suggested that a critical shortfall of this program was the release methodology, which subjected the lacewing eggs and neonate larvae to $60 \%$ to $80 \%$ mortality. Wunderlich and Giles (1999) developed a mechanical technique to safely release eggs in liquid suspension; however, adhesion of eggs to the vineyard canopy was an issue, and carriers have not yet been developed that improve "stick" while maintaining egg viability. Today, insectaries can produce lacewing adults, and this may be a more effective stage for release, especially when combined with an attractant to stimulate the adults to remain in the vineyard and deposit eggs on stalks - where they are not prone to predation by vineyard ants and spiders. Most insectaries produce Chrysoperla spp. because the adults are not predatory and can be reared on an artificial diet. Other common vineyard species include green and brown lacewings, which are predatory as adults and therefore more costly to rear.

Other generalist predators that are commercially available for augmentation include predaceous mites, minute pirate bugs and praying mantis. No information on their potential against mealybugs is known, and for that reason, they are not yet recommended for mealybug control.

Parasitoids may be a more effective natural enemy group for augmentative programs, but there are few studies of their use in California vineyards. Experimental release of $A$. pseudococci in a San Joaquin Valley raisin vineyard showed that vine mealybug abundance could be reduced by $50 \%$ with releases of 10,000 A. pseudococci per acre from June to July (fig. 4). Similar success has been reported in Israel using $A$. pseudococci for vine and citrus mealybugs (Daane, personal communication). The major limiting factor has been the commercial production of parasitoids and the cost per acre of release programs. Because many mealybug parasitoids are specialists, there is not one parasitoid species that can be commercially produced and used against all vineyard mealybugs. Recently, a number of commercial insectaries have shown an interest in producing $A$. pseudococci, a particularly good parasitoid for the vine mealybug. Other more specialized species may be good candidates for cooperative insectaries.

Pheromones. Sexually mature female mealybugs may emit a sex pheromone to attract the winged adult male mealybugs. These pheromones can be used to monitor mealybug populations and densities. Sex pheromones have been identified for the vine (Hinkens et al. 2001), obscure (Millar et al. 2005), grape (Bruno et al. 2007) and longtailed (Millar et al., unpublished data) mealybugs. Trials with the vine mealybug found that the parasitoid A. pseudococci was also caught in pheromone-

baited traps

(Millar et al. 2002). It was later observed that parasitism levels of vine mealybug were higher in vineyards with experimental mating disruption (Walton et al. 2006). Ongoing studies are screening the attractiveness of different parasitoid species to mealybug sex pheromones, to test the hypothesis that some parasitoid species spend more time searching for mealybugs in vineyards using a mating disruption program, thereby increasing parasitism rates.

\section{Role of vineyard characteristics}

While we presented information on biological controls for vineyard mealybugs, other sustainable control tools were not highlighted. For example, mealybug infestation levels may depend upon vine growth and fruiting characteristics, fruit maturation date and the type of pruning. Therefore,

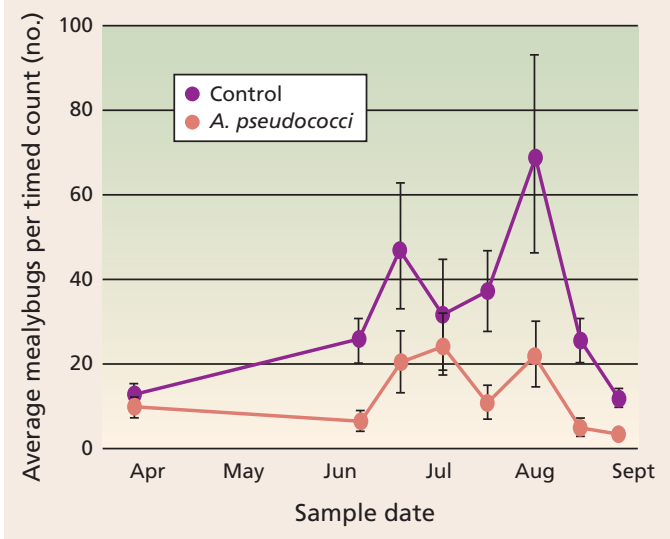

Fig. 4. Season-long average density per vine (for timed counts) of vine mealybugs was lower in treatments with Anagyrus pseudococci release, as compared with no-insecticide control plots. Source: Daane et al. 2004.

early-harvested varieties are much less likely to have serious fruit damage than late-maturing varieties because mealybug populations tend to increase with each new generation. Vigorous vines are more likely to be infested than weak ones, because mealybug egg production is lower on stressed vines (Daane et al., unpublished data). Most infested grape bunches are those that come in direct contact with the head or cordons of the vine, because most mealybug species find some refuge on the vine trunk for oviposition sites. Therefore, remov- 
Policy and Management, UC Berkeley; S.V. Triapitsyn is Principal Museum Scientist, Department of Entomology, UC Riverside; V.M. Walton is Assistant Professor, Department of Horticulture, Oregon State University; G.Y. Yokota is Staff Research Associate, Department of Environmental Science, Policy and Management, UC Berkeley; D.R. Haviland is Cooperative Extension Farm Advisor,
UC Cooperative Extension (UCCE), Kern County; W.J. Bentley is Areawide Advisor, UC Kearney Agricultural Center; K.E. Godfrey is Research Entomologist, Biological Control Program, California Department of Food and Agriculture (CDFA); and L.R. Wunderlich is Cooperative Extension Advisor, UCCE El Dorado and Amador counties.
We thank CDFA for funding this review; and the America Vineyard Foundation, California Table Grape Commission, California Raisin Marketing Board, Viticulture Consortium, Lodi Winegrape Commission (in cooperation with EPA District 9), Central Coast Vineyard Team, UC Statewide IPM Program, California Department of Pesticide Regulation and Western Regional SARE Program for funding mealybug research.

\section{References}

Bartlett BR, Clausen CP, DeBach P, et al. 1978. Introduced parasites and predators of arthropod pests and weeds: A world review. USDA Agricul Handbook No 480. Washington, DC.

Ben-Dov Y. 1994. A systematic catalogue of the mealybugs of the world (Insecta: Homoptera: Coccoidea: Pseudococcidae, and Putoidae) with data on geographical distribution, host plants, biology, and economic importance. Hampshire, UK: Intercept Ltd. $686 \mathrm{p}$

Bruno A, Figadère BA, McElfresh JS, et al. 2007. Trans- $\alpha$-Necrodyl isobutyrate, the sex pheromone of the grape mealybug, Pseudococcus maritimus. Tetrahedron Letters 48:8434-7.

Charles JG. 1985. Diadiplosis koebelei Koebele (Diptera: Cecidomyiidae), a predator of Pseudococcus longispinus T.-T. (Homoptera: Pseudococcidae), newly recorded from New Zealand. N Zeal J Zool 12:331-3.

Clausen CP. 1924. The parasites of Pseudococcus maritimus (Ehrhorn) in California (Hymenoptera Chalcidoidea). Part II. Biological studies and life histories. UC Pub Entomol 3:253-88.

Costello MJ, Daane KM. 1999. Abundance of spiders and insect predators on grapes in central California. J Arachnol 27:531-8.

Daane KM, Bentley WJ, Walton VM, et al. 2006. New controls investigated for vine mealybug. Cal Ag 60:31-8.

Daane KM, Cooper ML, Triapitsyn SV, et al. 2008. Parasitoids of obscure mealybug, Pseudococcus viburni (Signoret) (Hem.: Pseudococcidae) in California vineyards: Establishment of Pseudaphycus flavidulus (Brèthes) (Hym.: Encyrtidae) and discussion of reared parasitoid species. BioControl Sci Technol 18:43-57.

Daane KM, González D, Bianchi M, et al. 1996. Mealybugs in grape vineyards. Grape Grower 28(5):10,12.

Daane KM, Malakar-Kuenen R, Walton VM. 2004. Temperature development of Anagyrus pseudococci (Hymenoptera: Encyrtidae) as a parasitoid of the vine mealybug, Planococcus ficus (Homoptera: Pseudococcidae). Biol Contr 31:123-32.

Daane KM, Malakar-Kuenen R, Yokota GY, et al. 2001. Investigation of mealybug population dynamics to forecast and prevent outbreaks and improve biological controls. Calif Table Grape Comm Ann Rep Vol 29. $16 p$

Daane KM, Sime KR, Fallon K, Cooper ML. 2007. Impacts of Argentine ants on mealybugs and their natural enemies in California's coastal vineyards. Ecol Entomol 32:583-96.

Daane KM, Yokota GY. 1997. Release methods affect egg survival and distribution of augmentated green lacewings (Chrysopidae: Neuroptera). Env Entomol 26:455-64.

DeBach P, Fleschner CA, Dietrick EJ. 1949. Population studies of the long-tailed mealybug and its natural enemies on citrus trees in southern California. J Econ Entomol 42:777-82

Doutt RL, Hagen KS. 1950. Biological control measures applied against Pseudococcus maritimus on pears. J Econ Entomol 43:94-6.

Essig EO. 1914. The mealybugs of California. Monthly Bull, Calif State Comm Hort 3:18-143.

Flaherty DL, Peacock WL, Bettiga L, Leavitt GM. 1982. Chemicals losing effect against grape mealybug. Cal Ag 36(3):15-6.

Geiger CA, Daane KM. 2001. Seasonal movement and sampling of the grape mealybug, Pseudococcus maritimus (Ehrhorn) (Homoptera: Pseudococcidae) in San Joaquin Valley vineyards. J Econ Entomol 94:291-301.

González D. 1998. Biological control of the vine mealybug in the Coachella Valley. Calif Table Grape Comm Ann Rep, Vol 26. 4 p.

Grasswitz TR, Burts EC. 1995. Effect of native natural enemies on the population dynamics of the grape mealybug, Pseudococcus maritimus (Hom.: Pseudococcidae), in the apple and pear orchards. Entomophaga 40:105-17.

Grimes EW, Cone WW. 1985. Life history, sex attraction, mating and natural enemies of the grape mealybug, Pseudococcus maritimus (Homoptera: Pseudococcidae). Ann Entomol Soc Am 78:554-8.

Gullan PJ, Downie DA, Steffan SA. 2003. A new pest species of the mealybug genus Ferrisia Fullaway (Hemiptera: Pseudococcidae) from the United States. Ann Entomol Soc Am 96:723-37.

Gutierrez AP, Daane KM, Ponti L, et al. 2008. Prospective evaluation of the biological control of the vine mealybug: Refuge effects and climate change. J Appl Ecol 45:524-36.

Haviland D, Beede R, Godfrey K, Daane K. 2006. Ferrisia gilli: A new mealybug pest of pistachios and other deciduous crops. UC ANR Pub 8203. Oakland, CA.

Haviland DR, Bentley WJ, Daane KM. 2005. Hot water treatments to control Planococcus ficus (Hemiptera:

Pseudococcidae) in grape nursery stock. J Econ Entomol 98:1109-15

Hinkens DM, McElfresh JS, Millar JG. 2001. Identification and synthesis of the sex attractant pheromone of the vine mealybug, Planococcus ficus. Tetrahedron Letters 42:1619-21.

Millar JG, Daane KM, McElfresh JS, et al. 2002. Development and optimization of methods for using sex pheromone for monitoring the mealybug Planococcus ficus (Homoptera: Pseudococcidae) in California vineyards. J Econ Entomol 95:706-14.

Millar JG, Midland SL, McElfresh JS, Daane KM. 2005. (2,3,4,4-tetramethylcyclopentyl)methyl acetate, a sex pheromone from the obscure mealybug First example of a new structural class of monoterpenes. J Chem Ecol 31:2999-3005.

Miller D, Gill RJ, Williams DJ. 1984. Taxonomic analysis of Pseudococcus affinis (Maskell). A senior synonym of Pseudococcus obscurus Essig, and a comparison with Pseudococcus maritimus (Ehrhorn) (Homoptera Pseudococcidae). Proc Entomol Soc Wash 86:703-13.

Neuenschwander P, Hagen KS. 1980. Role of the predator Hemerobius pacificus in a non-insecticide treated artichoke field. Environ Entomol 9:492-5.

Noyes JS, Hayat M. 1994. Oriental Mealybug Parasitoids of the Anagyrini (Hymenoptera: Encyrtidae). London: Natural History Museum. 576 p.

Phillips PA, Sherk CJ. 1991. To control mealybugs, stop honeydew-seeking ants. Cal Ag 45(2):26-8.

Roltsch, BJ, Meyerdirk DE, Warkentin R, et al. 2006. Classical biological control of the pink hibiscus mealybug, Maconellicoccus hirsutus (Green), in southern California. Biol Contr 37:155-66.

Smith HS. 1916. Insect parasites and predators as adjuncts in the control of mealybugs. Monthly Bull, Calif State Dept Hort 5:108-14.

Smith HS, Armitage HM. 1920. Biological control of mealybugs in California. Monthly Bull, Calif State Dept Agricul 9:104-58.

Stafford EM, Kido H. 1955. Control of grape mealybug in California. J Econ Entomol 48:101-2.

Triapitsyn SV, González D, Vickerman DB, et al. 2007 Morphological, biological, and molecular comparisons among the different geographical populations of Anagyrus pseudococci (Hymenoptera: Encyrtidae), parasitoids of Planococcus spp. (Hemiptera: Pseudococcidae), with notes on Anagyrus dactylopii. Biol Contr 41:14-24

Walton VM, Daane KM, Bentley WJ, et al. 2006 Pheromone-based mating disruption of Planococcus ficus (Hemiptera: Pseudococcidae) in California vineyards. J Econ Entomol 99:1280-90.

Walton VM, Pringle KL. 2004. Vine mealybug, Planococcus ficus (Signoret) (Hemiptera: Pseudococcidae), a key pest in South African vineyards: A review. So Afr J Enol Viticul 25:54-62.

Wunderlich LR, Giles DK. 1999. Field assessment of adhesion and hatch of Chrysoperla eggs mechanically applied in liquid carriers. Biol Contr 14:159-67. 